\title{
The first total synthesis of nidulalin A, a dihydroxanthone possessing multiple bioactivities
}

The Journal of Antibiotics (2009) 62, 469-470; doi:10.1038/ja.2009.52; published online 3 July 2009

Nidulalin A (1) was isolated by Kawahara's group from the rice culture of an ascomycetous fungus, Emericella nidulans (Eidam) Vuill. var. lata (Thom and Raper) Subram. (anamorph: Aspergillus nidulellus, Samon and W Gams), strain IN-68. ${ }^{1}$ The structure of nidulalin A (1) was determined by X-ray crystallography and Mosher's method as well as by comparison of CD spectra with known xanthone derivatives. ${ }^{1}$ In the later studies, nidulalin A (1) was found to possess potent inhibitory activity against DNA topoisomerase II and immunomodulatory activity. ${ }^{2,3}$ Although natural products having the dihydroxanthone skeleton have been seen to be widespread, ${ }^{4-8}$ only a few total syntheses have been achieved., 90 Interested in the structure and bioactivities of nidulalin $\mathrm{A}$, we embarked on the synthetic studies of the natural product.

An overview of our total synthesis of nidulalin A (1) including the ORTEP drawing of X-ray crystallography of the key intermediates is disclosed in Scheme 1. (The spectrum<smiles>COc1cc(OC)cc(OC)c1</smiles>

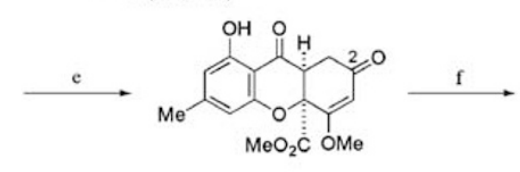

9<smiles>COC(=O)[C@]12Oc3cc(C)cc(O)c3C(=O)[C@H]1CC=CC2=O</smiles>

10

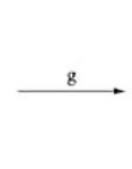

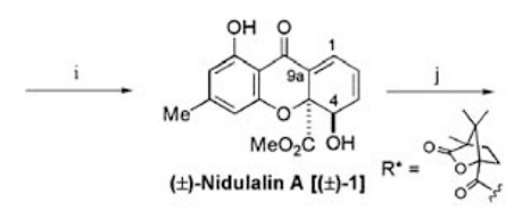<smiles>CCOC1Oc2cc(C)cc(O)c2C(=O)C2=CC=CC(OC)C21OC</smiles><smiles>CO[C@H]1Oc2cc(C)cc(O)c2C(=O)C2=CC=C[C@H](O)[C@]21C(C)(C)C</smiles><smiles>COC(=O)C=C1C(=O)c2c(O)cc(C)cc2OC1OC</smiles><smiles>CCCC</smiles><smiles>COC(=O)[C@]12Oc3cc(C)cc(O)c3C(=O)C1=CC=C[C@H]2O</smiles>
(+)-Nidulalin A (ent-1)

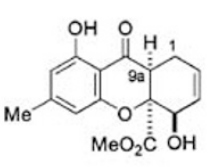

11

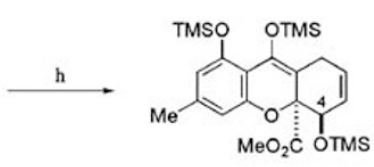

12

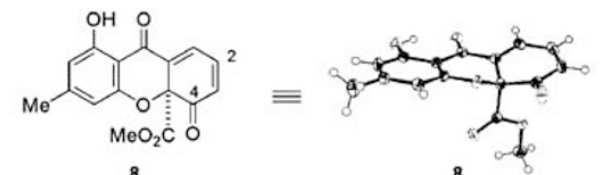

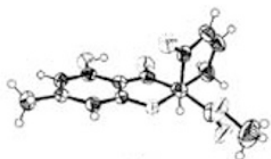

10

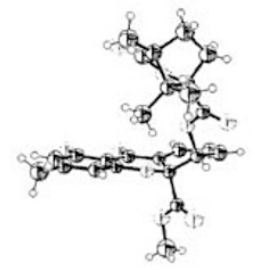

13

Scheme 1 Reagents and conditions: (a) MOMCl, NaH, DMF, $0{ }^{\circ} \mathrm{C}$ to rt, $40 \mathrm{~min}$, quant.; (b) $t$-BuLi, TMEDA, Et $\mathrm{O}_{2} \mathrm{O}-\mathrm{THF},-78$ to $-20^{\circ} \mathrm{C}, 2 \mathrm{~h}, 90 \%$; (c) $\mathrm{TsOH} \bullet \mathrm{H}_{2} \mathrm{O}, \mathrm{MeOH}$, reflux, $5 \mathrm{~h}$, quant.; (d) $\mathrm{Pb}(\mathrm{OAc})_{4}, \mathrm{AcONa}, \mathrm{MeNO}_{2}$, rt, $10 \mathrm{~min}, 39 \%$; (e) $\mathrm{NaBH}(\mathrm{OAc})_{3}, \mathrm{~B}(\mathrm{OAc})_{3}, \mathrm{THF}$, rt, $30 \mathrm{~min}, 79 \%$; (f) $\mathrm{DIBAL}$, THF, $-78{ }^{\circ} \mathrm{C}, 10$ min then, $6 \mathrm{~N} \mathrm{HCl}$, rt, $14 \mathrm{~h}$, quant.; (g) $\mathrm{LiAlH}_{4}, \mathrm{THF},-60^{\circ} \mathrm{C}, 2 \mathrm{~h}, 60 \%$ (recovery of SM, 30\%); (h) TMSOTf, $\mathrm{Et}_{3} \mathrm{~N}, \mathrm{CH}_{2} \mathrm{Cl}_{2}, 0^{\circ} \mathrm{C}, 1 \mathrm{~h}$; (i) $\mathrm{SeO}_{2}$, 1,4-dioxane, $50{ }^{\circ} \mathrm{C}, 20 \mathrm{~h}\left(60 \%\right.$ from 11); (j) (-)-camphanic acid, WSCl- $\mathrm{HCl}, 4-\mathrm{DMAP}, \mathrm{CH}_{2} \mathrm{Cl}_{2}$, rt, $30 \mathrm{~min}, 75 \%(1: 1) ;(\mathbf{k}) \mathrm{K}_{2} \mathrm{CO}_{3}, \mathrm{MeOH}^{\circ}{ }^{\circ} \mathrm{C}, 5 \mathrm{~h}, 80 \%$ for (-)-nidulalin A (1), 76\% for (+)-nidulalin A (ent-1). 
data of compounds in Scheme 1 as well as ${ }^{1} \mathrm{H}$ and ${ }^{13} \mathrm{C}$ NMR spectra of synthetic (-)-nidulalin A (1) are provided as supplementary information.) The total synthesis started with dimethyl 5-hydroxy-3-methoxyphthalate (2). ${ }^{11}$ The hydroxy group of 2 was protected as methoxymethyl ether to provide 3 , which was submitted to regioselective coupling to give ketone 5. Treatment of bis(methoxymethyl ether) 4 with $t$-BuLi in the presence of $N, N^{\prime}$-tetramethylethylene diamine (TMEDA) at $-78{ }^{\circ} \mathrm{C}$ produced regioselectively lithiated 4 , which reacted with diester 3 regioselectively at the $\mathrm{C}-1$ carbonyl group at $-20{ }^{\circ} \mathrm{C}$ to provide ketone $\mathbf{5}$ in $90 \%$ yield. Acid hydrolysis of $\mathbf{5}$ gave trihydroxyketone $\mathbf{6}$ in quantitative yield. Oxidative cyclization of 6 was performed with lead (IV) tetraacetate ( 2 eq) in the presence of sodium acetate (23 eq) to afford tricyclic 7 , the structure of which was confirmed by X-ray crystallography. (Crystallographic data (excluding structure factors) for the structures of $7,8,10,13$, 14, and 1 have been deposited with the Cambridge Crystallographic Data Center as supplementary publication numbers CCDC 728664 for 7,728665 for $\mathbf{8}, 728666$ for 10, 728667 for 13, 728668 for 14 , and 728669 for 1.)

1,2-Reduction of 7 at the C-2 position with DIBAL (in $\mathrm{CH}_{2} \mathrm{Cl}_{2},-78^{\circ} \mathrm{C}, 30 \mathrm{~min}$ ) followed by hydrolysis of methyl vinyl ether (addition of THF, $6 \mathrm{~N} \mathrm{HCl}, \mathrm{rt}, 2 \mathrm{~h}$ ) gave enone 8 (the ORTEP drawing is shown in Scheme 1). The hydride reduction of $\mathbf{8}$ gave 4-epi-nidulalin $\mathrm{A}$ exclusively. ${ }^{12}$ As the methoxycarbonyl group of 8 covered the $\alpha$-face of C- 4 carbon, hydride attacked the C-4 carbonyl group from the $\beta$-face to give the $\alpha$ alcohol (4-epi-nidulalin A). To invert the face selectivity, we set up cis-fused intermediate 10, which would be submitted to hydride addition from the $\alpha$-face (the convex face) to give $\beta$-alcohol 11.

The cis-fused 9 was derived by 1,4-reduction of the oxidative cyclization product 7 . The subsequent regio-selective reduction of C-2 ketone and hydrolysis gave enone $\mathbf{1 0}$ whose structure was determined by X-ray crystallography (the ORTEP drawing is shown in Scheme 1). The $\alpha$-face of $\mathbf{1 0}$ was situated as the convex face as expected. Enone $\mathbf{1 0}$ was submitted to regio- and stereoselective reduction to afford $\beta$-alcohol 11. To avoid reduction at the C-9 position of ketone 10, the reaction mixture was quenched after stirring at $-60{ }^{\circ} \mathrm{C}$ for $2 \mathrm{~h}$. Dehydrogenation to construct $\Delta 1,9$ a double bond of nidulalin A was performed in two steps. Treatment of ketone 11 with TMSOTf in the presence of $\mathrm{Et}_{3} \mathrm{~N}$ provided silyl enol ether 12 concomitant with protection of alcohol. Allylic oxidation of 12 proceeded with $\mathrm{SeO}_{2}$ at $50^{\circ} \mathrm{C}$, accompanied by de-O-silylation at position $\mathrm{C}-4$, to give $( \pm)$-nidulalin A $[( \pm)-\mathbf{1}]$. Spectral properties of synthetic $( \pm)-\mathbf{1}$ were identical with those of natural products including ${ }^{1} \mathrm{H}$ NMR, ${ }^{13} \mathrm{C}$ NMR, IR and MS. ${ }^{1}$

( \pm )-Nidulalin A in hand, we next examined resolving the enantiomers with a chiral auxiliary. Esterification of $( \pm)$-nidulalin A $[( \pm)-1]$ with $(-)$-camphanic acid gave diastereomers separable by silica gel column chromatography. The absolute structures of both isomers were determined by X-ray crystallography (the ORTEP drawing of $(4 R$, 4aS)-nidulalin A ester $\mathbf{1 3}$ is shown in Scheme 1). Saponification of camphanic ester of ( $4 R$, 4aS)-nidulalin A (13) gave orange crystals of 1 , the solution of which showed the optical rotation $[\alpha]_{\mathrm{D}}^{24}-570^{\circ}\left(\right.$ c $0.28, \mathrm{CHCl}_{3}$ ), levorotatory as the natural nidulalin $\mathrm{A}^{12}$ (orange needles, $[\alpha]_{\mathrm{D}}^{25}-463^{\circ}$ (c $\left.0.28, \mathrm{CHCl}_{3}\right)$ ). (4S, $4 \mathrm{a} R$ )-nidulalin A (ent-1) was also obtained from the other diastereomer 14 by the same procedure as above. $(4 S, 4 \mathrm{a} R)$-nidulalin A shows the optical rotation $[\alpha]_{\mathrm{D}}^{25}+569^{\circ}(c$ $0.28, \mathrm{CHCl}_{3}$ ), being (+)-nidulalin A. Therefore, (-)-nidulalin A was synthesized to confirm the structure of the natural product.

In conclusion, the first total synthesis of nidulalin A has been achieved. Construction of the stereogenic center at the C-4 position was accomplished through cis-fused tricyclic intermediate $\mathbf{1 0}$ to submit the stereospecific reduction. (-)- and (+)-nidulalin $\mathrm{A}$ was obtained from $( \pm)$-nidulalin A by derivation to $(-)$-camphanic esters.

\section{ACKNOWLEDGEMENTS}

This work was financially supported by the Consolidated Research Institute for Advanced Science and Medical Care, the Global COE program 'Center for Practical Chemical Wisdom, and Scientific Research on Priority Area 'Creation of Biologically Functional Molecules' from the Ministry of Education, Culture, Sports, Science and Technology. We also thank the Shorai Foundation For Science and Technology for financial support.

Kuniaki Tatsuta, Shusuke Yoshihara, Nobutaka Hattori, Shinpei Yoshida and Seijiro Hosokawa

Faculty of Science and Engineering, Department of Applied Chemistry, Waseda University, Shinjuku-ku, Tokyo, Japan

1 Kawahara, N., Sekita, S., Satake, M., Udagawa, S. \& Kawai, K. Structure of a new dihydroxanthone derivative, nidulalin $A$, and a new benzophenone derivative, nidulalin B, from Emericella nidulans. Chem. Pharm. Bull. 42, 1720-1723 (1994).

2 Sato, S. et al. Synthesis of novel antitumor dihydroxanthone derivatives with inhibitory activity against DNA topoisomerase II.. Bioorg. Med. Chem. Lett. 9, 2653-2656 (1999).

3 Fujimoto, H., Asai, T., Kim, Y.-P. \& Ishibashi, M. Nine constituents including six xanthone-related compounds isolated from Two ascomycetes, Gelasinospora santiflorii and Emericella quadrilineata, Found in a screening study focused on immunomodulatory activity. Chem. Pharm. Bull. 54, 550-553 (2006).

4 Tabata, N., Tomoda, H., Matsuzaki, K. \& Ômura, S. Structure and biosynthesis of xanthoquinodins, anticoccidial antibiotics. J. Am. Chem. Soc. 115, 8558-8564 (1992).

5 Parish, C. A. et al. Isolation and structure elucidation of parnafungins, antifungal natural products that inhibit mRNA polyadenylation. J. Am. Chem. Soc. 130, 7060-7066 (2008).

6 Hussain, $\mathrm{H}$. et al. Absolute configuration of globosuxanthone $\mathrm{A}$ and secondary metabolites from Microdiplodia sp.- - a novel solid-state CD / TDDFT approach. Eur. J. Org. Chem. 292-295 (2007).

7 Wijeratne, E. M. K., Turbyville, T. J., Fritz, A., Whitesell, L. \& Gunatilaka, A. A. L. A new dihydroxanthenone from a plant-associated strain of the fungus Chaetomium globosum demonstrates anticancer activity. Bioorg. Med. Chem. 14, 7917-7923 (2006).

8 Zhang, W. et al. New mono- and dimerc members of the secalonic acid family, blennolides A-G, isolated from fungus Blennoria sp. Chem. Eur. J. 14, 4913-4923 (2008).

9 Nising, C. F., Ohnemüller (née Schmid), U. K. \& Bräse, $\mathrm{S}$. The total synthesis of the fungal metabolite diversonol. Angew. Chem. Int. Ed. 45, 307-309 (2006).

10 Nicolaou, K. C. \& Li, A. Total syntheses and structural revision of $\alpha$ - and $\beta$-diversonolic esters and total syntheses of diversonol and blennolide C. Angew. Chem. Int. Ed. 47, 6579-6582 (2008).

11 Danishefsky, S. et al. Derivatives of 1-methoxy-3-trimethylsilyloxy-1,3-butadiene for Diels -Alder reactions. J. Am. Chem. Soc. 101, 7001-7008 (1979).

12 Sato, S. et al. F390B and C, new antitumor dihydroxanthone derivatives isolated from Penicillium sp. J. Antibiot. 50, 614-616 (1997). 